\title{
A History of Virulence: The Body and Computer Culture in the 1980s
}

\author{
ANTONIO A. CASILLI
}

\begin{abstract}
The recent turn in ubiquitous computing challenges previous theories of 'technological disembodiment'. In a mediascape where technology permeates bodies, the current discourse of viral information insinuates elements of fear and risk associated with both physical presence and computer usage. This article adopts a socio-historical approach to investigate the factors underlying the early emergence of such features of our social imaginary by tracking them back to the computer culture of the 1980s. Analysing both mainstream and underground press sources from 1982 to 1991, a discursive core is revealed that revolves around the 'computer virus' metaphor. Popularized in this period, this notion came to resonate with mounting moral panic over the HIV/AIDS epidemic. Anxieties about the body in computer culture are then conceptualized (and historically contextualized) along two dimensions: first, the political proximity between HIV/AIDS activists and computer hackers during the FDA clinical trials controversy of 1987-8; and, second, the ideological reinforcement provided by academic progressive elements to these political actions. The implications of these results are discussed.
\end{abstract}

Keywords body in computer culture, computer virus, hacker, HIV/AIDS activism, virality

\section{Ubiquity, Embodiment, Virality}

The emergence of ubiquitous media and the focus on pervasive computer networks seem to have introduced a major shift in the way information and communication technologies are practised and represented in contemporary societies. Since the early 2000s, the consensus around theories of a virtual humanity 'homesteading on the electronic frontier' - the ethereal cyberspace where users were to be 'uploaded' (Lévy, 1994; Rheingold, 1993) - have progressively given way to

Body E Society Copyright (C) The Author(s) 2010, Reprints and permissions:

http://www.sagepub.co.uk/journalsPermissions.nav

Vol. 16(4): 1-31; DOI: 10.1177/1357034X10383880 
approaches to computer-mediated social interaction centred on mixed realities. According to these new theoretical stances, digital technologies are to be regarded as a domain of affordances extending and enhancing physical presence rather than superseding it (Hansen, 2006). Significantly enough, the author who popularized the very notion of 'cyberspace', William Gibson, acknowledges this momentous development in his novel Spook Country: if the pre-ubiquitous technological paradigm can be described as 'a state in which "mass" media existed, if you will, within the world', in the ubiquitous one they 'comprise it' (2007: 121).

Ubiquitous computing does not transcend everyday experience, rather it pervades reality by saturating the actual space of the cities and by infusing physical bodies. Featherstone (2007:320) describes this media ontology by suggesting that 'as media become ubiquitous they become increasingly embedded in material objects and environments, bodies and clothing, zones of transmission and reception'. After Simondon, Bernard Stiegler defines social and ubiquitous media as a 'human techno-geographical milieu' (in Venn et al., 2007), that is, a socio-technological process converting human corporeality into information. Following Stiegler's emphasis on the need to harmonize symbolic, technical and material milieus, new couplings of the body, social imaginaries and social practices come into view.

As far as all reality can be considered as a mixed reality, the theoretical issue at stake is what the social and cultural mechanisms are for allowing the mutual introjection of information and communication technologies (ICTs) and human life. Knorr Cetina and Preda (2007) aptly remark that the distinctive feature of contemporary communicational systems is their capacity to subsume and, at the same time, to project the life-world. Digital embodiment, thus intended as one that does not renounce physical presence yet reconfigures it in a dialectical exchange with the technological artefacts, emerges as the central topic of contemporary computer culture. In contrast to the early warnings of the renunciation to the 'real' body (Le Breton, 1999; Moravec, 1988; Muri, 2003), more recent trends in science and technology studies point towards the dismissal of the 'disembodiment' hypothesis (Casilli, 2009a; Hayles, 2009).

This, nonetheless, leaves open the question as to the historical reasons why the set of theories insisting on technologically induced disembodiment prevailed in the first place. In this article I will maintain that both the disembodied and the ubiquitous discourses surrounding the body and information technologies represent the actualization of a certain cultural feature, namely a rhetoric of virulence, which is not new to computer culture. Contemporary focus on 'viral' circulation of online contents on the Internet and its impact on the economic and political spheres (Krishnamurthy, 2004; Painter, 2002) echoes elements of biological and informational danger that have been evident since the early years of 
mass computing. The biological metaphor also mirrors a social dynamic based on the premise of the information permeating the body. Following in the current trend of research addressing the societal impact of information and communication technologies in a historical perspective (Bell, 2007; Bell et al., 2004; Sterne, 2006; Tofts et al., 2003), the present article aims to examine the emergence of this rhetoric as a historically situated construct resulting from the juxtaposition of two social processes: (1) the reaction of mainstream media and public opinion to burgeoning autonomous computer usage on a potential mass level; (2) the alliance of computer activists and HIV/AIDS rights advocates, relying heavily on technological expertise to promote public campaigns challenging biomedical authorities and public health policy-makers.

After presenting the methodology, this article consists of three main parts: (1) it reviews mainstream media narratives of computer virulence and computer hacking; (2) it examines sources emanating from computer-specialized milieus; then (3) it attempts to contextualize the contents of these two bodies of sources from a socio-historical point of view. Some concluding remarks are presented in the final section.

\section{Methodology}

\section{Sources}

Mainstream press and underground publications dealing with computer use provide an opportunity to examine how notions and beliefs surrounding the body have been expressed, both in written and iconographic form. Html versions of newspaper articles and scanned files of specialized publications from the 1980s were analysed to gain insight into how the discourse of virulence was built, both inside and outside computer culture.

The main sources analysed were of two types: written and iconographic. The first set of sources was extracted from the online LexisNexis Executive service. A body of 654 articles and newswires published between 1 January 1985 and 1 January 1991 in English-speaking international publications was examined. ${ }^{1}$ The second set of sources was extracted from specialized publications targeting computer users. The analysis was carried out both on the underground press (31 issues of the German-language journal Datenschleuder, dated 1984 to 1991) ${ }^{2}$ and on the consumer press both in French and English (31 selected images, dated 1982 to 1990). ${ }^{3}$

\section{Data Analysis}

Originally developed in sociolinguistics, cultural studies, semiology and hermeneutics (Fairclough, 2003), the methodology selected for the data analysis adopts 
Table 1

Organizing themes for the two inventories of sources

\begin{tabular}{lcc}
\hline Organizing themes & Inventory $a$ & Inventory $b$ \\
\hline Medical authority & $\mathrm{x}$ & \\
Body-machine metaphors & $\mathrm{x}$ & $\mathrm{x}$ \\
Military & $\mathrm{x}$ & \\
Death & $\mathrm{x}$ & $\mathrm{x}$ \\
Sexuality & $\mathrm{x}$ & $\mathrm{x}$ \\
Epidemic & $\mathrm{x}$ & $\mathrm{x}$ \\
Nourishment & $\mathrm{x}$ & $\mathrm{x}$ \\
Individual risk-taking bebaviour / safety & $\mathrm{x}$ & $\mathrm{x}$ \\
Intimacy & & $\mathrm{x}$ \\
Drugs & $\mathrm{x}$ & \\
\hline
\end{tabular}

Berthelot's (1992) classical approach of the social aspects of embodiment, consisting in construing the body as a 'discursive operator'. The analysis of the discourse structuring its imaginary and behavioural aspects in a given society involves discerning unities of discourse, listing them and grouping them in threads.

A system of category codes was developed through an iterative reading of the articles (first set of sources), and through an examination and comparison of images (second set of sources). The approach involved isolating units of analysis (either written passages or details of images) and identifying threads and visual tropes. The units were then coded according to dominant themes and arranged into two parallel non-hierarchical inventories.

In what follows, the units extracted from written sources (inventory $a$ ) have been classified into nine themes, whereas the iconographic ones (inventory $b$ ) are classified into seven themes (see Table 1).

The way these themes are ordered in each inventory is informed not only by logical criteria but also by historical ones. The method used to structure the inventories of themes is borrowed from cultural history and mainly consists in the creation of series of sources (de Baecque, 1993; Wodak, 2001), with subsequent interpolation of these series with synchronic axes. Each axis provides a transserial snapshot of the serialized units at a given moment.

This two-step procedure not only allows links to be established between elements of the same logically consistent series but also (through the insertion of synchronic axes) provides a socio-historical contextualization of the object in the series. As a result, unanticipated ties between units and themes belonging to different series can be detected. Figure 1 presents two generic series of five themes each. Elements are arranged in ascending numerical order in series $(a)$ and in descending order in series $(b)$. One theme from each series can be intersected at 


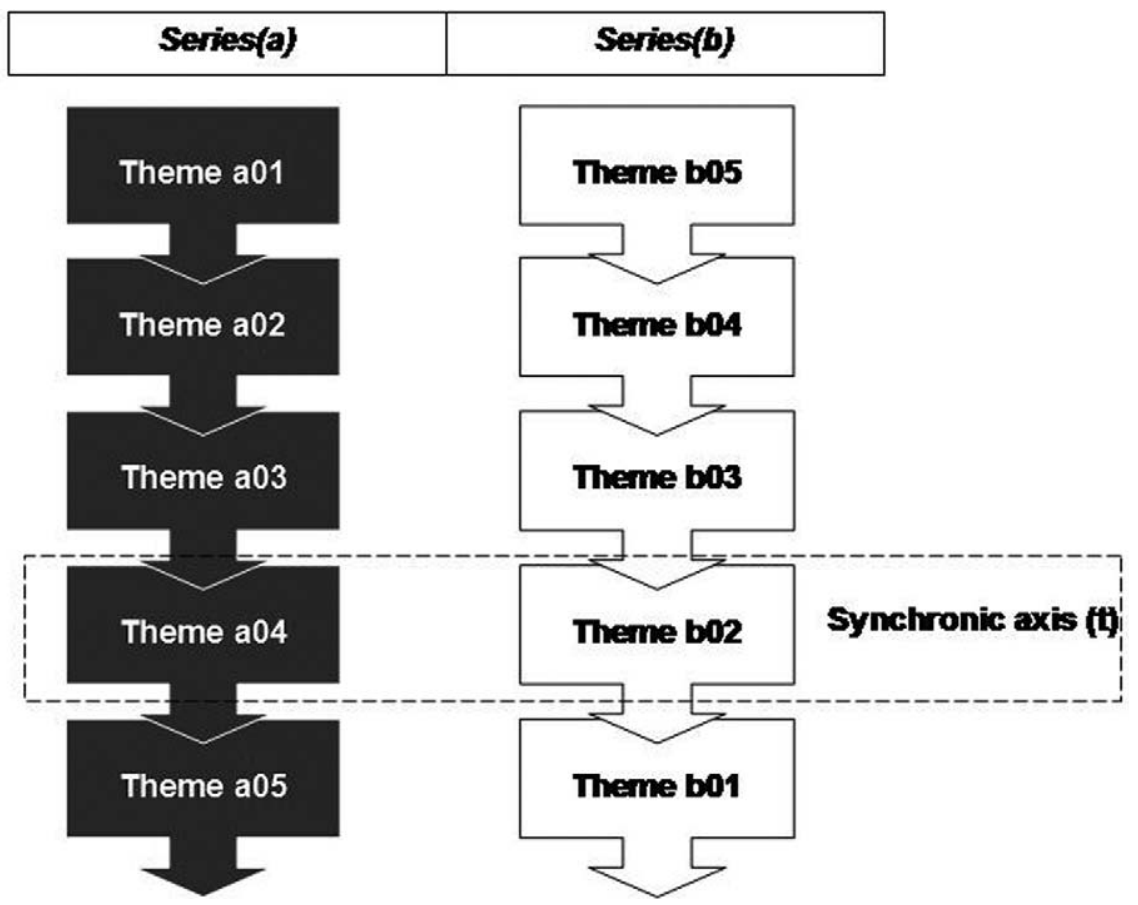

Figure 1. Interpolating series of themes with synchronic axes

moment $(\mathrm{t})$, thereby establishing an interrelation that would have been otherwise undetectable.

The advantage of this approach is that it potentially avoids the functionalist fallacy consisting in interpreting a particular social construct resulting from the unique combination of certain elements of discourse - and thus contingently conditioned by socio-historical events encompassing the context of enunciation - as invariant within a given culture, or across cultures.

\section{Historiographical Approach}

The historical methodology adopted in this article mainly draws upon the French and continental European school of bistoire culturelle (Kalifa, 2008; Poirrier, 2008). Borrowing from previous trends in history of mentalities (Burke, 1986) and anthropological history (Burguière, 1999), this brand of cultural history deals with the developments in human relations and knowledge as expressions of social movements and emerging actors in a given society. Specifically, this approach has focused on the study of the influence on specific bodily imaginaries of social, technical and institutional factors (Vigarello, 1988). 
Cultural history has been mainly regarded as an exit strategy from positivistic linear paradigms inherited from the 19th century (Chartier, 1998). In this sense, the use of 'series' does not have to be interpreted as an alignment with a historiographical tradition aiming at the establishment of a Lyotardian metanarrative. What is at stake here is not a comprehensive explanation of historical knowledge, but rather a 'thick' description of a specified social event - namely, the emergence of a distinctive discourse of the body. Michel de Certeau (1975) famously defined a social event as a 'limit' or a 'blind spot' of the logic of fact successiveness brought about by historiography. Therefore, the serialization of objects and cultural artefacts employed in the present article does not have to be interpreted as necessarily contributing to an organization of meanings that would ultimately subsume antinomic viewpoints in a grand narrative. If, to a certain extent, each attempt at historic writing is a 'disguised performative discourse through which an apparently factual observation turns out to be nothing more than the signifier of a speech act being an act of authority' (de Certeau, 1975: 133), by spelling out its temporal, material and logical structure, cultural history does not point towards the establishment of 'truth' - it merely aspires to outline the formative process of a cultural field. In the words of Pascal Ory, it is not the historians' work 'to probe the hearts of all those who [e.g.] have been visited by the Holy Virgin in 19th-century Catholic countries. But their scientific work must consist in studying the scripts, the contexts, the regularities and the specificities of those apparitions' (2004: 107).

In this sense, as stated above, the discussion of the results below outlines a historical event not according to periods and facts, but according to the social and cultural context where they become meaningful (McCloskey, 1988).

\section{Computer Viruses: Inscribing Computer Culture in the Biomedical Domain}

At the moment of their introduction, new social practices associated with computational artefacts were perceived as inhabiting a legal and cultural grey area. In the second half of the 1980s, autonomous computing ${ }^{4}$ - a loose definition that encompasses semi-legal computing activities such as file downloading, sharing and free-code development - started to be linked with pollution and contagion. As the media attention to the AIDS pandemics reached its peak, the mainstream press began adapting metaphors of virulence and 'unsafe behaviours' to autonomous computing, thereby creating one of the most interesting features of late 20th-century technological discourse: the notion of computer virus. Initially popularized within the software engineering community around 1984, this 
expression designated a malicious code with the ability to modify other computer programs and turn them into 'infectious malware'. In this section of the article, I will examine how the discourse of computer contagion came into common use and became the central element of a moral panic campaign in subsequent years. ${ }^{5}$

The analysis of mainstream press sources provides an overview of the shifts of metaphoric and semantic associations played out in newspaper stories. The turning point of this development can be situated in the year 1988. Before that date, the metaphors that were most commonly associated with malevolent computer use were of military origin. Hackers would 'attack' and 'invade' operating systems in order to 'spy' on them, or even install 'logic bombs'. Malicious software codes would exploit system 'vulnerabilities' and cause 'breaches in security'. Around 1988, this military terminology is progressively abandoned in favour of other metaphoric turns. In the corporate world, for instance, management of the 'health of the information technology environment' starts to be coupled with the management of the health of the employees. The tip-off is provided by a short Associated Press newswire. The title itself explicitly endorses the imaginary superposition of bodily pathology and computer malfunction:

\footnotetext{
COMPUTER VIRUSES ARE HIGH-TECH COUNTERPARTS OF BIOLOGICAL VIRUSES - Just as a biological virus disrupts living cells to cause disease, a computer virus is a parasitic computer program that invades data processors and reproduces itself to disrupt normal operation of the machines. Biological viruses are pieces of the hereditary code that take over a living cell's machinery to trick it into making thousands of duplicates of the original virus, infecting more cells to cause disease such as AIDS, which cripples the cells that defend the body against infection. (Associated Press, 1988)
}

The parallel between the body and computers is thus established. The keywords are all in place: 'virus', 'AIDS', 'infection'. To see how they play out in this body of literature, it is useful to look at a second theme, that of medical authority. Computer security experts are indeed compared to medical practitioners. Management is exhorted to use security professionals 'just as they would use a medical professional when serious illness threatens' (Wilder, 1988). From this point on, metaphors are mostly drawn from a discursive repertoire that revolves around the idea of virulence. Described as 'illnesses' jeopardizing informational 'health', viruses allegedly create a need for the 'doctoring' of electronic artefacts. The trade names developed for the first commercial antivirus 'medicines' are unequivocal: Data Physician, AntiDote, Flushot, Panacea (Rosenberg, 1988). There is no cause for surprise that the threat embedded in computer use is described as a hazard for the user's bodily integrity. As governments allegedly recognize their powerlessness to fight hackers via warfare or law 
enforcement tools, the only way a computer epidemic could be policed journalists maintained - is by assigning to each and every citizen the mandatory management of risk-taking behaviours. In the press, reports of the damage produced by computer viruses become cautionary tales, comparable to the moralizing discourses on hygiene in the early 20th century. Far from being simple metaphors, these warnings against the propagation of infections urge a new 'civilizing process' that addresses both corporeal and digital behaviours. ${ }^{6}$

HIV/AIDS, as the distinctive disease of the 1980s, came to play a major role in the computer virus imaginary. Reaching further into the intimate sphere, technological contamination is purported to be able to take the form of a sexually transmittable disease. While commenting on the arrest of Robert T. Morris - a young software engineer accused of having launched the first self-replicating 'worm' (at the time an exotic type of computer virus) on the Internet (at the time, an almost unheard of computer network) - security experts let slip that 'with Robert in hand, safe computing, like safe sex, is attainable' (Associated Press, 1988). The effort to exploit widespread sexual anxieties encouraged industry actors to push even further the inscription of autonomous computing practices into the linguistic domain of biomedicine. Hospitals, pharmaceutical companies, scientific research centres, became the new elective targets of 'computer criminals'.

Hacking thereby increasingly becomes a problem of public health. The pharmacoms are first in the firing line. A Financial Times article rather blatantly compares computer pirates attacking the electronic system of a condom producer to the Chicago extortionist who was responsible for the infamous 1982 Tylenol case (Abrahams, 1988: 17). Apart from the reference to sexually transmissible diseases (implied by the very nature of the business targeted), computer intrusions are held responsible for obstructing private companies in their search for a solution to AIDS and for forcing them out of business (Abrahams, 1988: 17). Hospitals were soon added to the long list of victims of computer misdemeanours. Although, as a matter of fact, clinical establishments were reported having suffered hacker intrusion even prior to $1988,{ }^{7}$ in the wake of the computer virus moral panic, 'computer criminals' are customarily accused of interrupting therapies, damaging clinical equipment, and threatening the safety of doctors and patients.

Moreover, media commentators agree that medical files are easy prey for hackers. In a 1985 Australian press agency report, the theft of sensitive data is depicted as an actual danger for all Queensland users, who - it is claimed - would be defenceless against blackmail by computer-savvy youths (Rodgers, 1985). In 1988, the authorities of the Australian state of Victoria are accused of not having adequately protected the personal data of the donors to a sperm bank. This 
alleged incompetence exposes the donors to the unpleasant possibility that the babies that had been born might 'come knocking at their door' because of possible breaches of the electronic databases containing their name and address (Peak, 1988).

As if the shadow of blackmail was not enough of an intolerable blow to individual privacy and safety, other, far more tangible, catastrophes are conjured up in the event of computer delinquents targeting healthcare services. Malicious software could potentially infect data relative to important research projects, a scientist from the UCSF declares to a Christian Science Monitor reporter (Bradley, 1988). But, a few lines on, he contradicts himself: not only does the hospital keep a printed back-up of these data files but their research computers aren't even online. All the same, computer experts and media agree in saying that 'a virus in a hospital computer would create a chaotic, perhaps life-threatening, situation' (Bradley, 1988: 3). Although the actual danger to the medical establishment is extremely limited, autonomous computer activities could pose threats to patients for the simple reason that they throw the therapeutic process into confusion. Clinicians are ideally depicted as dealing with severe illnesses and life-or-death situations. The slightest interference is therefore presented as having potentially fatal consequences. The main concern expressed by the medical community is that hackers' displays of technological proficiency distract them from their main task - 'saving lives' (Harrison, 1988).

When real events do not quench newspapers' thirst for computer virus stories, outrageous hypotheses passed on by self-appointed experts are used instead. Press features turn into pulp fiction, providing lurid details and vague information when it comes to places, dates, persons concerned. Ironically, this vagueness has the unexpected consequence of universalizing such stories by reinforcing their exemplary character:

In one incident, an unidentified hacker gained access to the computerized patient records of $a$ Los Angeles hospital and changed all intensive-care patients' entries to double the prescribed drug dosages. Fortunately, hospital officials discovered the penetration before the altered records caused potentially fatal drug overdoses. (Wood, 1988: 28, emphasis added)

The similarity between computer viruses and AIDS invites management of the risk not only at the individual level. Once an association is established between data safety and potential death threats, the epidemiological implications come to be seen as threatening to society as a whole. The anxiety surrounding the connection between computers comes to mirror the bundle of fears that surround bodily contact. Whether organic or electronic, these two types of communication both become inscribed in a biomedical frame of virulence. After 1988, the general public started perceiving HIV/AIDS not as a problem confined to certain 
minorities (homosexuals, Haitian immigrants, intravenous drugs users, etc.). HIV/AIDS could strike 'anybody anytime'. Sexual exclusivity, prophylaxis, security measures aimed at preventing the spreading of the epidemic were not in themselves sufficient any more. A similar evolution is detectable in the discursive structures of the debates about computer misuse.

This point is made all the more vivid in one of the most striking media stories of the late 1980s: the AIDS diskette saga. On 7 December 1989, 26,000 computer diskettes containing an 'interactive program for health education on the disease called AIDS' were sent throughout Europe and Africa from an obscure London-based company. While users were to answer an electronic questionnaire that assessed risk-taking behaviours and suggested strategies for coping, the diskette installed another piece of software - a trojan horse that would lock the hard disk and display a message asking payment for an annual licence subscription of US\$189. Evidence collected by Scotland Yard was inconclusive. Some of the addressees included participants of the previous year's World Health Organization (WHO) Stockholm AIDS international conference. The rest were subscribers to the magazine PC Business World. The producer of the software turned out to be a shady organization called PC Cyborg Corporation, based in Panama. However, the country was virtually inaccessible at the time because of the US military operation to overthrow General Noriega's regime. An unexpected set of coincidences (the finding of a PC Cyborg rubber stamp during a routine baggage inspection at Amsterdam Schiphol Airport) eventually led to the arrest of an American citizen: Harvard-trained anthropologist Joseph Popp. Popp himself was an associate of the Flying Doctors, a branch of the African Medical Research Foundation (AMREF), and a consultant for the WHO in Kenya, where he had organized a conference in the new Global AIDS Program that very year. ${ }^{8}$

The media pounces on the news scoop, which perfectly fits into the previous discursive thread. The story has all the right ingredients: an electronic threat, a police mystery and a terrifying disease. The AIDS diskette case is initially presented as yet another assault on medical institutions by a subversive computer criminal. The damage caused to hospitals and other health establishments by the trojan horse is exaggerated. The financial loss, initially estimated at the stratospheric amount of $£ 6$ million, pales by comparison with the alleged public health threat represented by the malicious diskette. The Guardian announces that 'several' diskettes have been sent to medical research laboratories (Large, 1989). The Australian Advertiser maintains that a London charity dealing with AIDS prevention has received 'several hundred copies' of the software (Murche, 1989). The Washington Times, for its part, reports that an 'uncertain number' of 
European hospitals have been hit by the virus (Richman, 1989), and that catastrophe was avoided in the US thanks to the prompt mobilization of AIDS researchers. ${ }^{9}$

After the main suspect is arrested, the press persists in playing up the threat to public health by emphasizing the anthropologist's doctoral title. 'Dr Popp' comes to be portrayed in the media not as a computer extortionist, but as a maverick scientist engaged in a lone project of medical prevention and information dissemination. Emphasis is put on his links to HIV/AIDS research, the WHO and African medical associations. According to The Guardian, Popp was on a mission for WHO to study AIDS in Africa only a few months before his arrest (Brasier, 1990).

The AIDS diskette is unlike previous computer hacking stories. All the tropes of computer virulence are portrayed, but in a more complex and ambiguous way. The hacker is assuredly designated as the carrier of the malicious code. But, paradoxically, his computer virus is designed to fight a real-life one. Dr Popp is presented as a heterodox practitioner aiming to heal through computing. An Associated Press newswire of February 2nd, 1990 describes him as a 'medical-informatic consultant' (Associated Press, 1990a). Not a clinician, but a healer working in AIDS education, or rather a 'specialist ... developing informational programs' promoting a new kind of information-driven treatment (Pane, 1990: 43). 'The Doctor' is no ordinary hacker, just a non-conformist health specialist, and a rebel against the medical establishment. He is led to hatch his diabolical plot because of his 'frustration with the pharmacom-ridden medical research on human immunodeficiency' (Connor, 1991). Between the lines, it becomes clear that Popp's autonomous computing activity is intended to promote an alternative model of medical research. In his press statements, the anthropologist himself poses as an adversary to his former employer, the WHO, and official health policies. His scheme is, in his words, aimed at raising funds for alternative research and for non-profit HIV/AIDS organizations. 'The sole reason for the project', he insists, 'was to use computers to provide health education to people around the world to fight the global epidemic of AIDS' (Associated Press, 1990b).

Over a two-year period, the dramatic tension around 'deadly viruses' polluting computers reaches new heights in the mainstream media. A simple metaphoric juxtaposition between bodily and technological contamination triggers a complex narrative weaving together intimate fears and public health risks, physical and informational dangers, threats to the body and threats to communication technologies. The AIDS diskette story represents an unexpected turn in the virulence discourse. This dystopian parable turns out to contain a utopian promise: 
the spreading of a computer virus comes to represent the possible end of a physical disease. This paradox, as I will explain in the next section, is also one of the main features of the discursive construction of virulence in the specialized and underground computer press.

\section{Computers - Viral or Visceral?}

This 'viral turn' in mainstream computer narratives was absorbed in a somewhat paradoxical way into users' milieus. The symbolic coincidence of the body and computing machinery, as well as the related viral motives, were enthusiastically adopted by computer amateurs. This appropriation can be read as a typical ironic strategy mirroring hegemonic taxonomies (Ang, 1985; Storey, 2006), a way of transcending labelling through self-stigmatization. In this sense, virulence developed into a cultural process of unapologetic 'counterpride display' typical of youth subcultures (Richards, 1988). In the context of 1980s computer culture, this can be interpreted as something that aimed not only to empower autonomous social practices through political recognition but also to normalize personal motivations and behaviours through the inscription of technological activity in the intimate sphere of the body. The mimicking of the media hype was not only performed with satirical intent. It also performed a deliberate distortion and amplification of the viral discourse into one of 'viscerality'. The classical Cartesian superposition between body and machine - implied by the mainstream rhetoric of computer viruses - expanded into a thematic sequence that came to be dominated by the image of the machine penetrating the body.

Understanding how computer culture adopted the stigma of being a 'virus' and turning it into an asset requires first understanding the relative place and status of the computer in late 20th-century consumer culture. The process of miniaturization of computing technology that had led from the 13-ton UNIVAC (1951) to the 30-odd kilo IBM 5100 (1975) was also a process of re-territorialization. While the post-war 'electronic giant brains' (Berkeley, 1949) occupied military bunkers and industrial basements, the 1980s saw the infiltration of computing machines into the private sphere. Decades before ubiquitous computing, home- and family-computers took up residence inside the houses of a new generation of electronic amateurs. ${ }^{10}$ Commercial names changed in step, evoking everyday life and homely informality. The most successful products had common male and female names like Lisa or Vic. ${ }^{11}$ They conjured up the unthreatening pleasures of family life: children (Junior, Piccolo), small animals (Pet, Bee), and fruits (Apple, Acorn, etc.). ${ }^{12}$ Products designating power, luxury and imposing size were destined to sell poorly. ${ }^{13}$ Specialized press targeting computer users developed these motifs. 


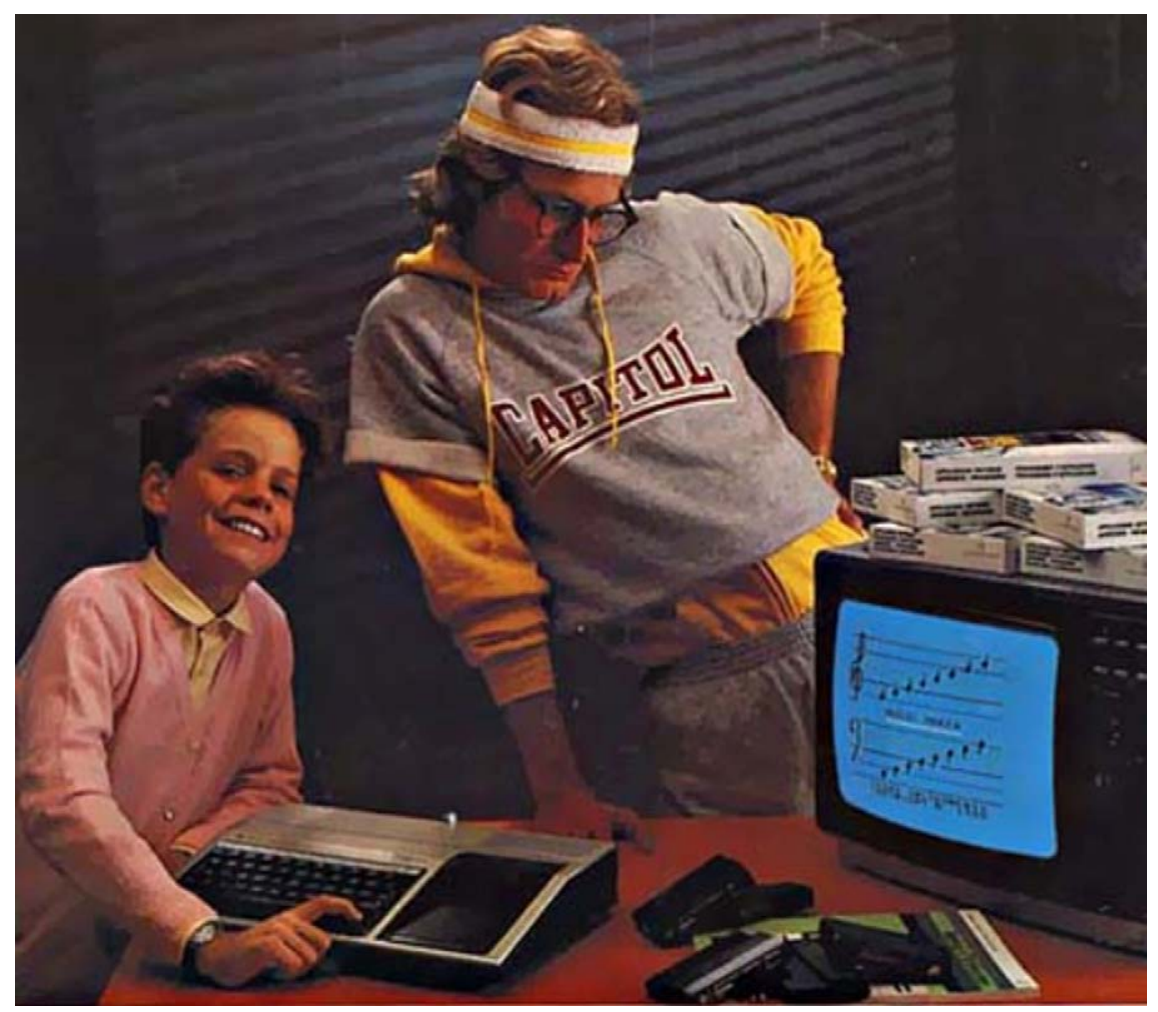

Figure 2. Family computer and physical exercise (Anon., 1983a)

Home privacy became synonymous with personal, bodily intimacy. In the media, there was an increasing trend to emphasize the association between autonomous computing and bodily performance, beauty and health. The well-known Apple 1984 TV commercial (Scott, 1984), ${ }^{14}$ for example, staged the liberating power of personal computers by opposing a young female athlete to a crowd of senile users living under the rule of an Orwellian Big Brother.

These initial remarks are corroborated and extended by the analysis of visual sources. At first glance, the depictions of computers associated with sports and physical activities duplicate this buoyant bodily imaginary. For example, Figure 2 clearly places the computer in a family setting. The presence of a father and his son suggests intergenerational unity and family ordinariness. The father wearing sports gear further indicates that computing can be seen as a substitute for physical exercise.

Figure 3 similarly stages the complementarity of physical exercise and computing: a woman sitting on the floor of her living room is performing an aerobic routine, following the gestures and positions displayed on the computer screen 


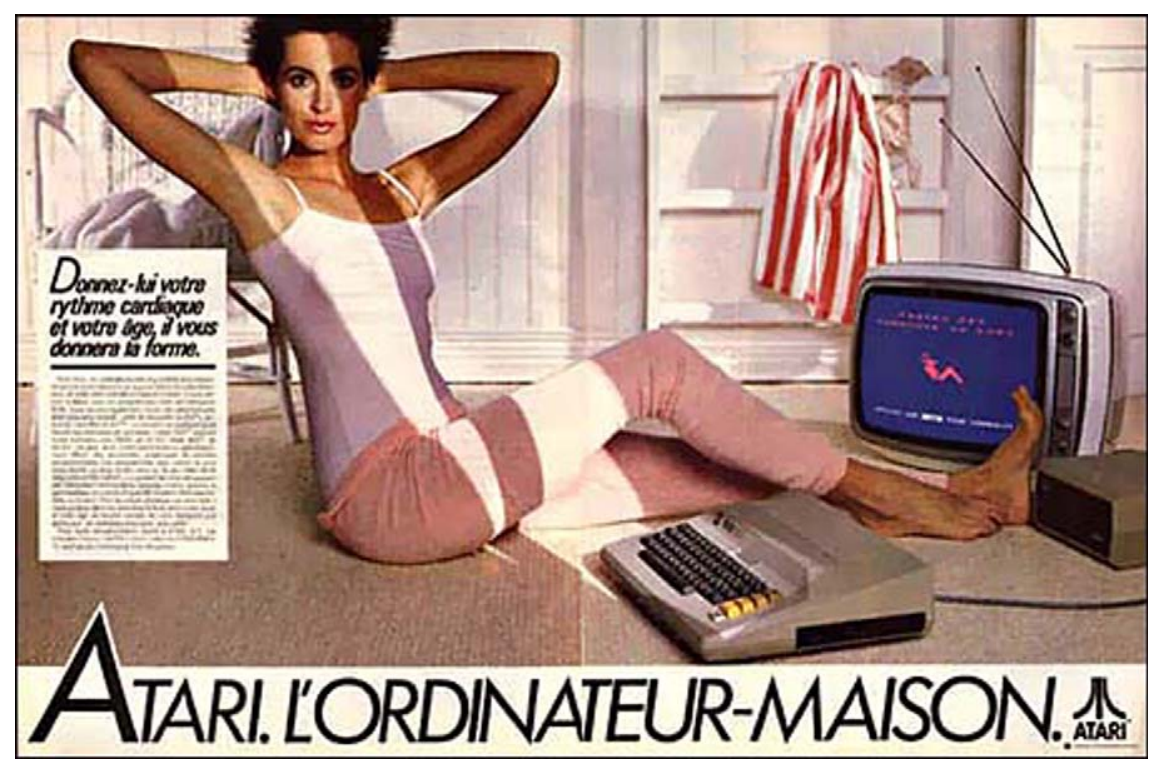

Figure 3. Personal computer enables physical performance (Anon., 1983b)

placed in front of her. The copy reads: 'Enter your heart rate and your age, and it will put you back into shape.'

In this context, the emphasis placed on the private dimension of the technological experience exorcizes the perils associated with public spaces: computers are 'safe as houses'. Yet, underneath this positive imaginary, something else takes shape. Computers are getting closer to the body, touching it. A hand strokes the mouse, a face approaches the screen, a chest leans over the keyboard. New, 'portable' micro-computers virtually begin to stick to the body, to the trunk, to press against the entrails. In Figure 4, the French computer journalist Alain Tailliar strikes a pose in an old promotional press photo that is precisely a testimony of the surfacing of a new visceral approach to computer usage.

Although the size of the computer in the image might bring a smile to the face of present-day readers, at the time it clearly aimed to present an overoptimistic, idealized vision of information technology. But the handsome, openhearted Cary Grant-type character also betrays an inner tension, which is exemplified by his squinting eyes and his clutched hands. The rigid gesture of his two arms is the central element here, as they round off in a circle, to bring the computer close to the stomach and squeeze it against the torso to interiorize, to embody it.

Eminent voices in the computer underground, who were actually never far from commercial culture, echo this fascination. Bruce Sterling describes the new information technologies as 'pervasive, utterly intimate'. Personal computers are 


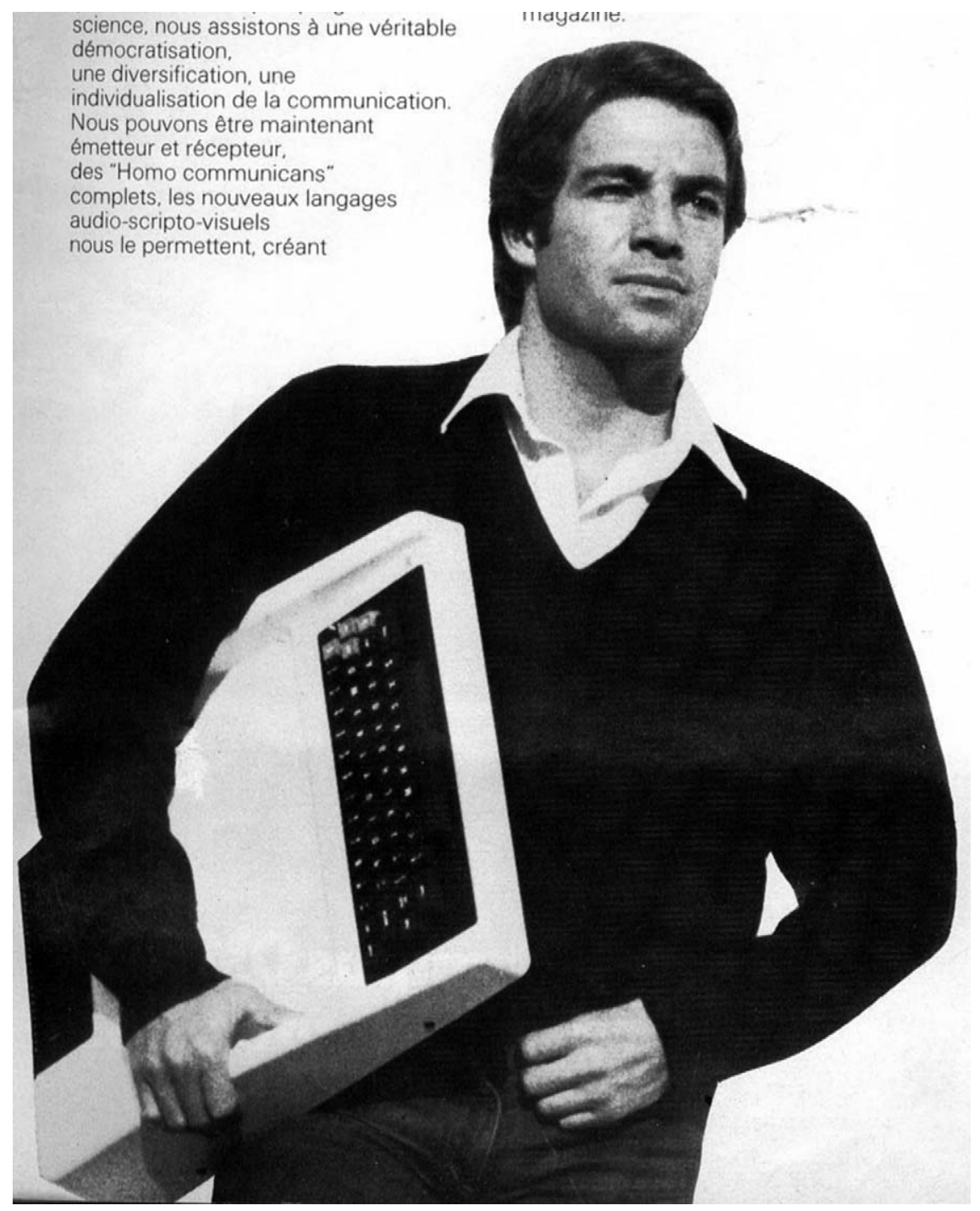

Figure 4. The computer 'sticks to the body' (Anon., 1982)

no longer external to their users, but next to them: 'Eighties tech sticks to the skin' (Sterling, 1986: 12) and sometimes it even goes so far as to penetrate under the skin and into the body. The 1986 'Hacker Manifesto' (The Mentor, 1986) effectively completes the metaphor by comparing computer hacking to intravenous drug use. ${ }^{15}$ References to HIV/AIDS and risk-taking behaviours are not alien to the computer iconography of these years, but, in comparison with the written resources examined in the previous section ('Computer Viruses: 
Inscribing Computer Culture in the Biomedical Domain'), they are more tangibly connected to images of internal circulation, secretion and subcutaneous pulsation. Viscerality hooks up with virality in conveying a bodily imaginary which relied heavily on deep organs, entrails and fluids. This discourse is best highlighted in the iconography of the German hacker fanzine Die Datenschleuder. ${ }^{16}$ The theme of sexuality recurs throughout the first issues, used as a means to alternate technical articles, political commentaries, spoof and satirical illustrations. The cover of issue no. 19 (Figure 5), features a scene of seduction. In a richly furnished bedroom, a libertine kisses and fondles a sensuous lady revealing her generous cleavage. While the lovers touch each other, their hands wander over the keyboard of an elegant 18th-century decorated computer.

The inclusion of electronic artefacts in the intimate sphere of their users is here overplayed to the extreme. The family is condensed into the couple, the living room becomes a bedroom, and innocent playfulness is misrepresented as foreplay. If in the specialized commercial computer press, the technological artefact commanded a libidinal investment from its consumer, here it releases the unashamed display of a libidinous behaviour.

Also, in the case of Die Datenschleuder the logical gap separating the intimate/private sphere from the corporeal one is bridged. The hacker fanzine starts playing with the motif of the bodily assimilation of computers, going so far as to suggest that computers are edible, ready to be absorbed and literally incorporated by their users. A collection of mock 'Gastrocybernetic' computer cooking recipes proposed in issue no. 17 (Anon., 1986a: 13) paves the way for a restricted but significant set of images published around 1988, representing users actually eating computer terminals (Figure 6).

The desire for computing that in Figure 5 took the form of sexual urge, here becomes hunger for information. Not only it is suggested that computers are an object of appetite, but also that the final locus of information is the inner recesses of the body itself.

In the hacker imagery, people are presented as eating, fondling and making love to technological artefacts. The close relationship between technology and the human body would soon foreshadow notions of contamination, pain and agony. However, prior to 1988 it is the elements of fun and play that tend to predominate in the description of the symbiotic fusion between humans and computers. If virality is evoked, then it is done through representations that depict the virus floating over, or 'riding', the body and its organs such as, for example in Figure 7. Humour and sexual innuendos are still quite present in this image, but they are also mingled with a diffuse sense of dread and danger, exemplifying what Van Loon (2002) dubs as 'the jouissance of viral terrorism'. The human 


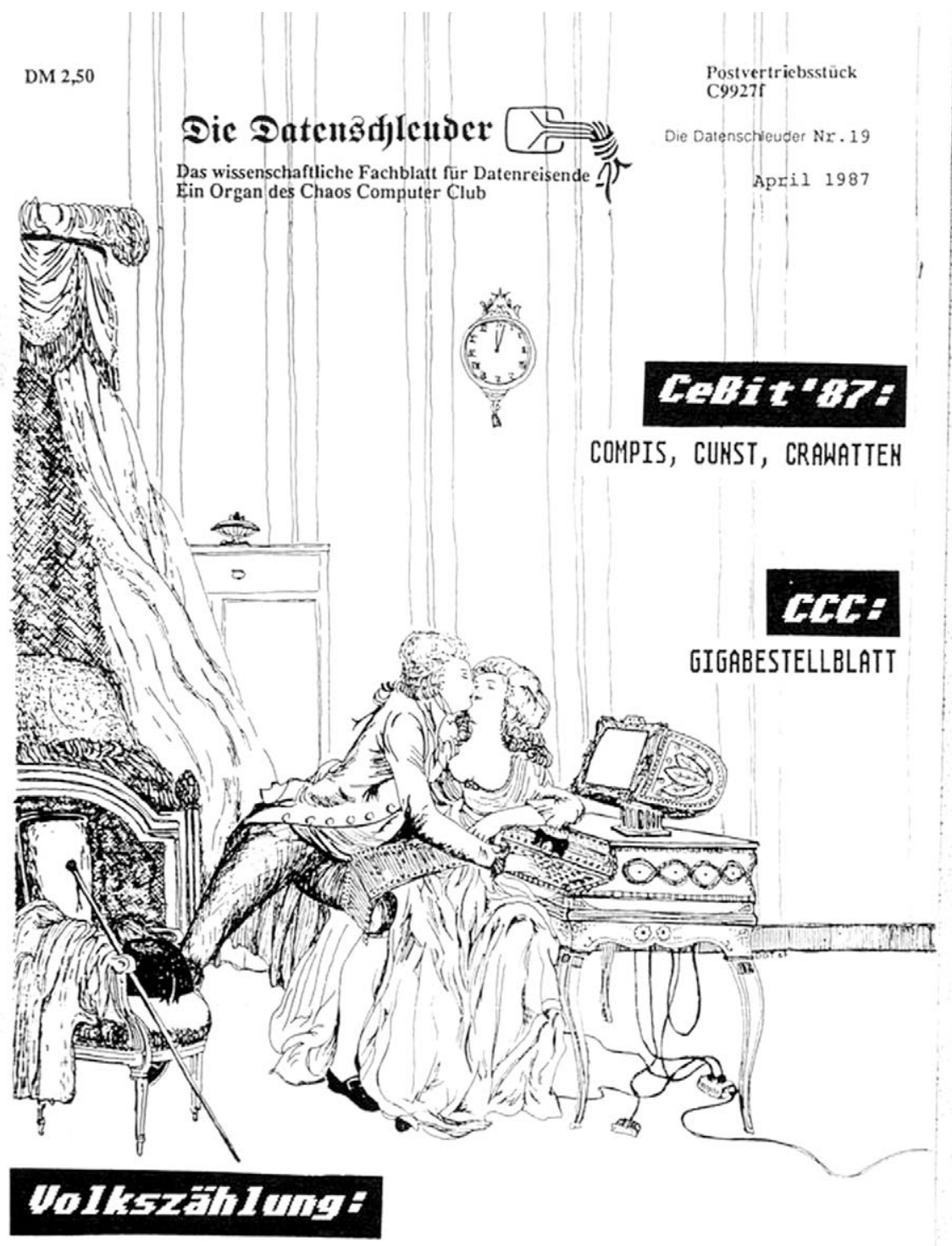

DAT, DATER, AM DATESTEN

Figure 5. Sexualizing the computer: parody of computer 'intimacy' in a 1980s hacker fanzine (Anon., 1987)

anatomy and the virus are presented as sharing the same nature (they are both 'bugs', which is what seems to be suggested by the brain's cockroach legs). Even so, they remain two distinct objects, and do not permeate each other. 


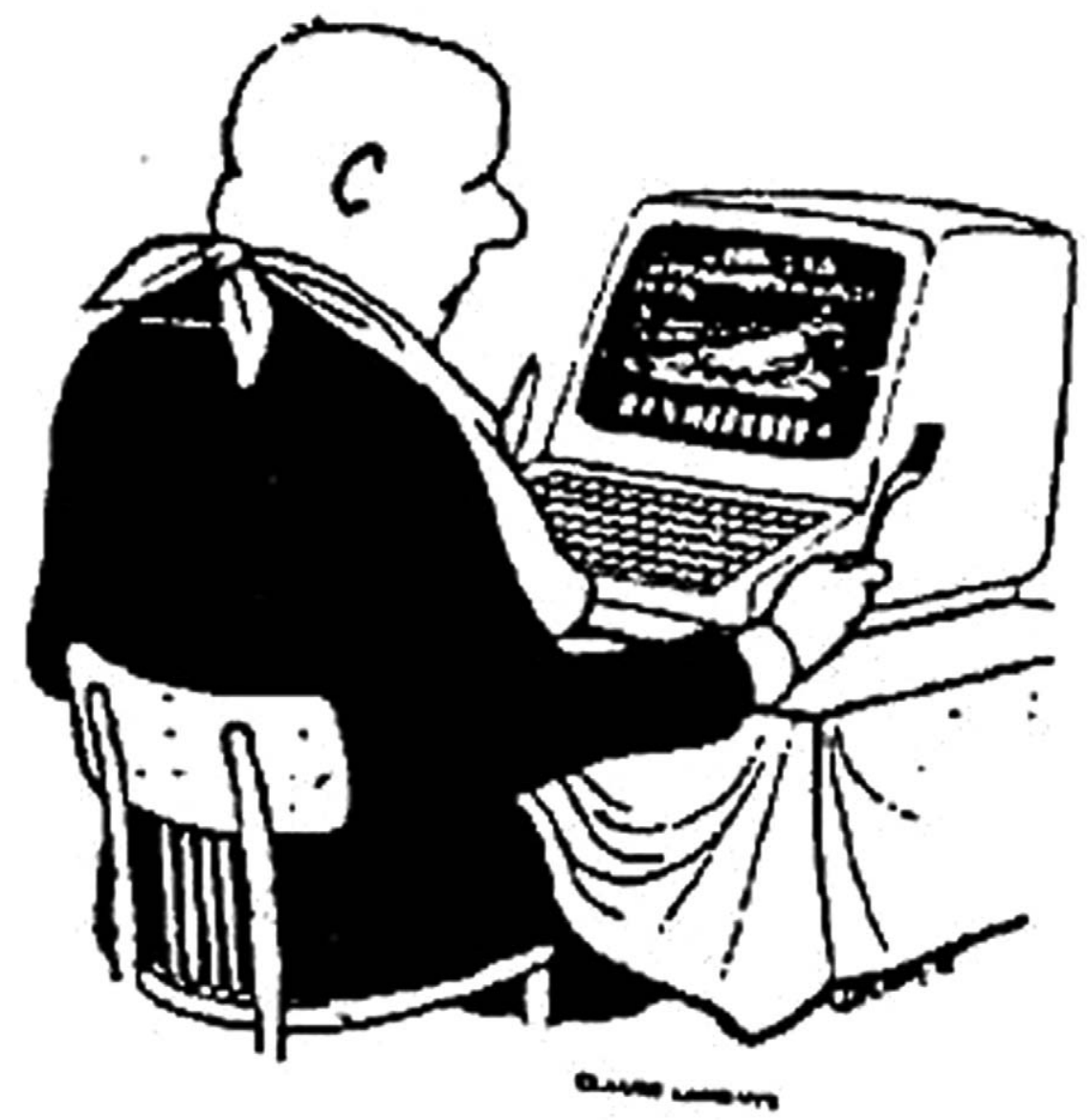

Figure 6. Hunger for information: incorporating the computer through ingestion (Anon., 1988)

For permeation to occur, the dense and solid qualities of the organs need to be liquefied. Playing on a macabre repertoire, German hackers start exposing physical decadence and necrosis. On the same synchronic axis used to analyse the mainstream press sources in the previous section ('Computer Viruses: Inscribing Computer Culture in the Biomedical Domain'), the motifs of computer virality and viscerality become detectable after 1988. The user's body comes to be represented as a corpse 'secreting' information as a blister would secrete pus. On the cover of issue no. 30 (Figure 8), an animated skull mocks the German postal authorities warning: 'This communication might have been opened for inspection'. To add morbidity to the image, from the zipper-lined open wound on the top of the skull, a slimy substance spurts out. 


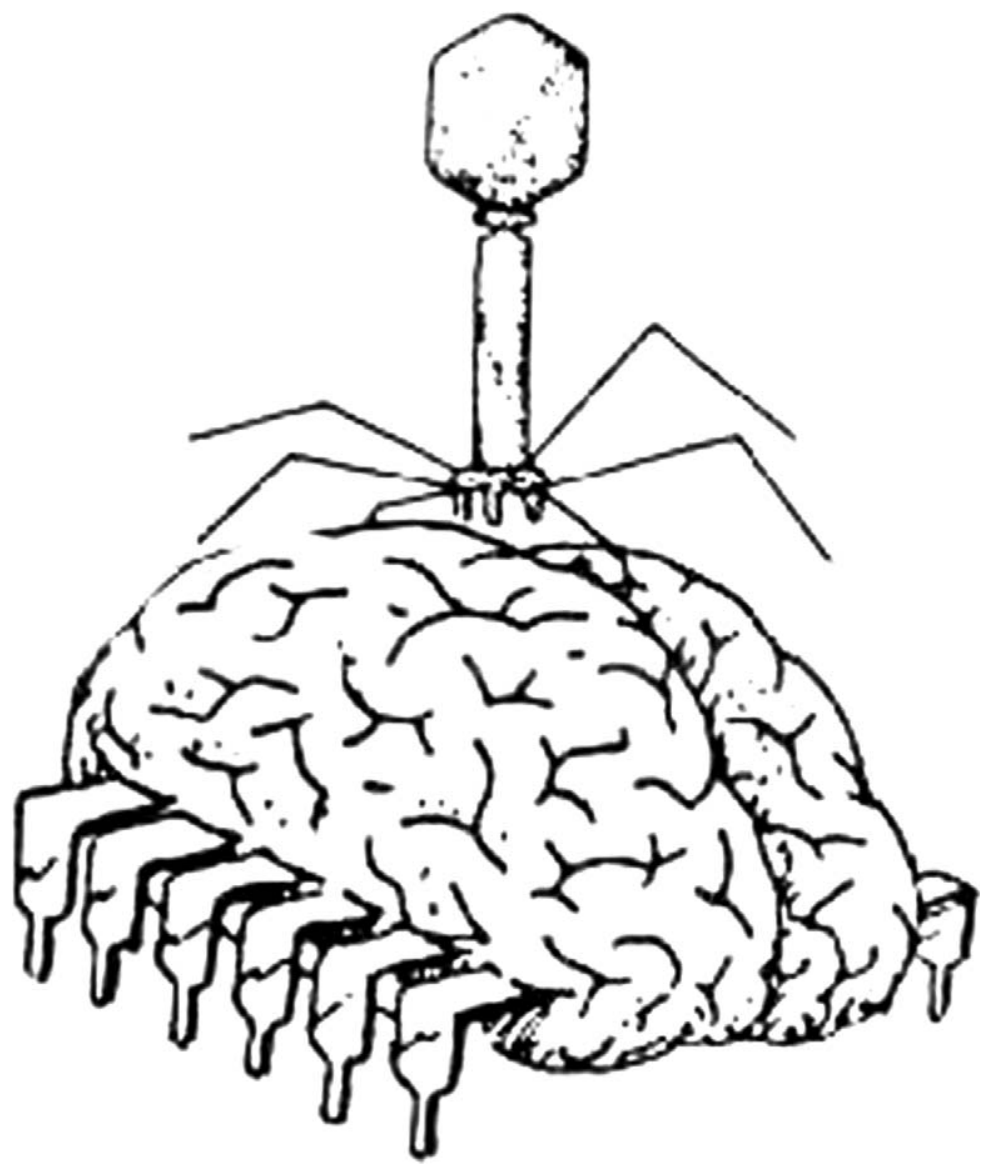

Figure 7. The virus 'riding' the organs of the body (Anon., 1986b)

The sinister jubilation that underlies this type of image could be interpreted as a provocation, a satirical exaggeration of the media discourse. What in the mainstream newspapers is mere insinuation is openly and loudly proclaimed in the hacker fanzine. This contamination clearly works to evoke images of fluidity and liquidity. The virus inside the skull turns the brain into seepage. Information becomes a disease circulating in the body, which is obviously evocative of the liquid elements of the AIDS/HIV narratives - semen, blood, etc.

\section{How to Have a Body in an Epidemic}

The parallel unfolding of motifs of virulence in two different media contexts shapes a discursive repertoire that interconnects computer safety to public health 
I S N N $0930-1045$

DM 3,00

\section{Die Datengdjlenider}

Das wissenschaftllche Fachblatt för Datenreisende

Ein Organ des Chaos Computer Club

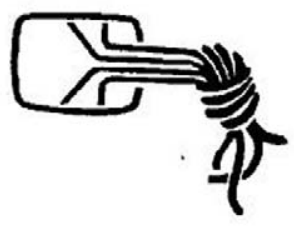

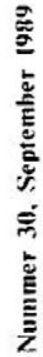

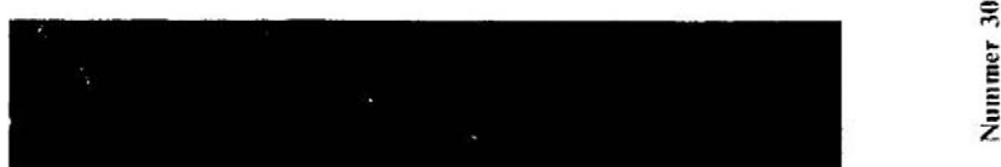

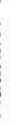

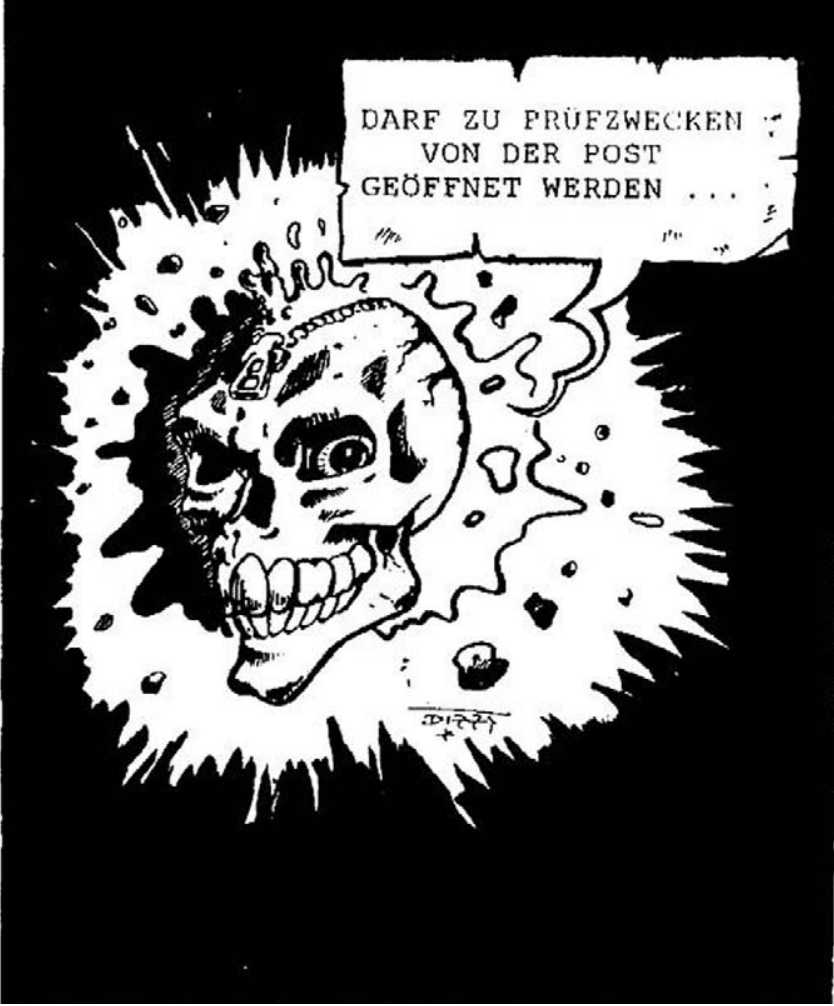

Figure 8. Informational virus as liquid infection (Dizzy, 1989)

issues, and technological artefacts to the body. Explaining that requires a better understanding of the strong discursive link between computer virulence and the AIDS moral panic, which can be achieved by taking into account the social and cultural circumstances surrounding computer culture in the 1980s. The HIV/ AIDS pandemic was actually the sign of a deeper crisis in the controlling and protective function that the biomedical establishment (clinical professionals, 
scientific research experts, pharmaceutical companies, public health agencies, etc.) had exerted over the body throughout the 20th century. As clearly pointed out by Cooper (2006), the 1980s was a time of 'epidemiological transition': on the one side $\mathrm{WHO}$ and the $\mathrm{UN}$ announced the defeat of infectious diseases; on the other, major epidemics made a spectacular come-back. While welfare-reduction policies were cutting down public health expenditure, a wide array of new pathogens, infectious and autoimmune diseases would emerge, in both developed and developing countries. The gap between the initial optimism of public health experts and the reality of the dramatic resurgence of infectious diseases may account for the obsessive presence of viral motives within the social imaginary. The sublimation of the viral threat in computer culture may be interpreted, at first glance, as a paradoxical reaction to the failure of medical research.

A wide-ranging social movement took shape around HIV/AIDS patients, challenging institutional medicine on an international level. The massive use of information technologies, mediated through the presence of a strong core of computersavvy activists and members of electronic bulletin boards (Gillett, 2003), is a verified feature of this movement. Activist users indeed started setting up networks of HIV/ AIDS patients, families, self-help groups and alternative practitioners immediately after the advent of micro-computers. Telecommunications and informatics were at the very core of these 'electronic civil disobedience networks ${ }^{17}$ promoting computer-assisted therapeutic alternatives, conjoining claims and political actions that until then had been dispersed.

Some of the most influential pioneers of online communities launched groundbreaking initiatives, such as San Francisco's Aids Treatment Newes bulletin or the electronic resource centre Critical Path. ${ }^{18}$ Between 1985 and 1990, several BBS and online databases were made available to HIV/AIDS patients and to their families and friends. Electronic forums such as AIDSInfo, Nerwsbase Computer or the Gay and Lesbian Electronic Access Network shared articles and up-to-date advice concerning new treatments and prevention. Via computer networks, users throughout the world even managed to attend remotely the Stockholm WHO Congress of 1988 (James, 1988a). In the wake of Cleveland's Saint Silicon experiment - a telemedicine service that put patients in direct contact with physicians - new modembased medical advice services were launched throughout Europe and Japan (Grundner and Garrett, 1986; Ikegami, 1997).

As highlighted by Linda Singer (1993) the HIV/AIDS epidemic resulted in an authoritarian discourse in light of which bodies were mobilized, resources were dispensed, and tactics of surveillance and regulation were justified. In order to counter this political and cultural orientation, computer clubs and hacker collectives helped the creation of underground buyers' clubs and clandestine 
associations of HIV/AIDS patients purchasing drugs on foreign markets and advocating alternative therapeutic frameworks. Their contribution is also attested in the disclosure of medical information protected by intellectual property laws (Casilli, 2009b).

On the occasion of the 'FDA clinical trials controversy', autonomous computer users turned out to be crucial for sharing information and coordinating political efforts among militant groups opposed to the US medical authorities (mainly the Food and Drugs Administration and the Surgeon General). This key event revolved around the efforts deployed by US activists to oppose the rigid and time-wasting FDA drug-testing protocols which, according to HIV/AIDS rights advocates, constituted an obstacle to the discovery of effective treatments. All new treatments were routinely submitted first to in vitro analyses (studies of the biochemical characteristics of the drug and animal trials), and then tested in vivo on human subjects. The standard double-blind clinical trial protocol entailed the creation of control groups, the members of which were given simple placebos instead of new (and presumably effective) drugs. From the point of view of the HIV/AIDS community, this standard biomedical method resulted in placebo subjects actually being denied access to potentially successful treatments. Moreover, this process in most cases would take up to seven years from the moment the new treatment was submitted to the FDA, to the moment it was approved for market sale. Facing a scenario of global pandemic, this delay appeared disproportionate for people living with AIDS. In 1987, a massive campaign aiming at a relaxation of the protocols was initiated. The campaign, which would ultimately lead to the deregulation of clinical trials on new HIV/AIDS treatments in the US, represented a momentous event in the history of computer culture and AIDS activism alike, combining their efforts to 'put drugs into bodies' while minimizing medical mediation (Treichler, 1991).

In 1988, San Francisco-based Project Inform, the newborn ACT UP, as well as Aids Treatment News (and several other fellow publications), started developing channels of scientific and technological communication. Electronic forums and independent computer bulletins were especially decisive for the organization and execution of several community-based trials, as well as for the successful dissemination of the results (Epstein, 1995, 1996; James, 1988b). These independent experiences successfully managed to place the rights of HIV/AIDS patients for treatment before the internal logics of biomedical institutions and pharmaceutical companies.

Significantly, these events are situated on the synchronic axis that intersects the outbreak of themes of virulence in the mainstream press (see the section 'Computer Viruses: Inscribing Computer Culture in the Biomedical Domain') 
and of virality/viscerality in the hacker press ('Computers - Viral or Visceral'). Despite their distinctive succession of themes, both series of sources seem to point to 1988 as being a turning point in the way that the body was featured in press stories about ICTs. The discursive association between autonomous computer users and HIV/AIDS patients is in fact indicative of the formation of a social and political alliance at a particular historical moment. This might also provide a first clue as to why computer culture (especially the hacker scene) did not try to counter the imaginary and discursive association between autonomous computing and virulence. By means of electronic communication and information-sharing, HIV/AIDS patients were increasingly empowered to take a stand and directly challenge public health decision-makers. Computer culture actually helped in the promotion of non-standard therapeutic procedures as well as of critical thinking about contemporary biomedical research. It turned out to be the key to a nascent political subjectivity - one aiming to question clinical powers and their modalities of hierarchical thinking - in its bid to reappropriate the body as a site of direct participation in social life. The goal of this particular brand of computer user collectives and early online communities was to disseminate medical expertise and multiply the number of actors who were entitled to have a say in the means of bodily treatment, and thus to overturn the prerogatives of the medical establishment over the body.

But another important element influenced the development of the computer virulence discourse: the political reinforcements these militant activities received from the academic milieus of the 1980s. The HIV/AIDS epidemic became the arena in which an array of scholars with no affiliation to medical institutions, but loosely associated with cultural and media studies, launched an attack on the biomedical vision of the body (Lupton, 1994). In the wake of her Cyborg Manifesto (1985), Donna Haraway had already intervened on the subject of virulence by drawing attention to the elements of symbolic and material discrimination that were hidden in the notion of 'immune system' (Haraway, 1989). Capitalism, as a socio-historical construction, she claimed, was built upon the 'purity of the immune system', that is, on the institution of a socially acceptable bodily norm that legitimized the exclusion of all non-conformist subjects. As spreaders of biological and electronic plagues, HIV/AIDS patients and computer hackers were ripe to join forces with academia's progressive elements against the 1980s Moral Majority. In taking a common political stance, a shared discursive orientation materialized. The academic left started 'pleading for virulence' as the only way out of the corporeal anxieties of the 'panic body' (Kroker and Kroker, 1987). To embrace contamination, to dive into the ecstasy of virulence turned out 
to be the way to declare that, even in the face of the HIV/AIDS epidemic, corporeality was still possible.

The adoption of the viral metaphor over the military one that - as shown at the beginning of the section on 'Computer Viruses: Inscribing Computer Culture in the Biomedical Domain' - was hegemonic in the years prior to 1988, turns out to be inspired by a precise political strategy. The centrality of martial images, it has been suggested (Waldby, 1996), proved to be functional to the setting of a political and epistemological order where efforts needed to be mobilized in the name of a 'war on AIDS' - and correspondingly of a 'war on computer crime'. In both fields, the use of military metaphors was intended to evacuate the potential for political antagonism. Eclipsing the presence of computer and AIDS activists alike, media military metaphors tended to divert public attention from social conflicts to a warfare in which only two proper sides (science versus the virus) were detectable. On the other hand, the hacker strategy of accepting virality as inherent to both computer use and bodily experience was intended to subvert from within the logic of immunity - both for organisms and for data. As argued by Allison Fraiberg (1991), the distinctive trait of techno-organic embodiment was its proclivity to contamination. Abandoning any pretension to immune defence, social actors of the information society came to be reconfigured as a matrix of intercommunicating and inter-contaminated AIDS-bodies: ' $[\mathrm{t}$ ] he traditional, tenuous limits of the body dissolved into fused networks, into open circuits of interconnectedness' (1991: 21). The adoption of a rhetoric of virulence would allegedly enable the development of a whole set of polymorphous activities that were designed to subtract the denizens of a technology-intensive society from the 'traditional sites of authority' over the body, namely 'bio-medical research, the Surgeon General, governmental and legal policy decisions' (1991: 28).

Exchanging blood and bodily fluids came to overlap symbolically with exchanging computer files and hardware components: two mutually reinforcing illustrations of the same phenomenon of transgressing the boundaries imposed by clinical powers on the body.

\section{Conclusions}

In the above sections, I have argued that the contemporary ubiquitous media approach to the technological body is rooted in a cultural process that originated with the rise in mass awareness of risks related to both computers and to the body in the mid 1980s. Such pairings of apocalyptic and utopian visions of the body were promoted by computer culture chiefly via the construction of discourses about 'electronic' viruses (Van Loon, 2002). The focus on the interplay of cultural, 
institutional and material factors in the construction of the body as a social fact (Detrez, 2002) contextualizes the bodily imaginary of computer culture within the socio-political tensions surrounding computer virulence and the HIV/AIDS epidemic of the 1980s. A set of chronologically concurrent events - generally linked to mass computing and medical controversies - has consolidated the association between material embodiment and informational virality. The rise of a discourse of electronic contamination takes place within the framework of the social conflicts touching on the body - the way it is perceived, regulated, administered. In this respect, this fear illustrates the incessant questioning to which medical powers have been subject during the second half of the 20th century (Turner, 1987).

Indeed, 1980s computer virulence can also be understood as a prelude to the utopias of virtualization and 'digital regeneration' of the body that emerged in the following decade. If contamination is perceived as deep-seated in the human body, then human beings themselves, given their material anatomy, are constantly exposed to infection troubling the sterilized world of biomedical prophylaxis. Consequently, early 1990 s 'virtual realities' came to be saluted as a timely cultural response to the fear trends of the 1980s (Babiole, 1992) and a solution to the stalemate of modern biomedical visions of corporeality. Besides the dreams of disembodiment propagated by the Californian pioneers of 'cyberdelia' (Barlow, 1990) or by the heralds of transhumanism (Ross, 1992), applications of virtual realities to surgery, drug design and medical training were among the first to be contrived by their creators. At the world premiere of the datagloves prototypes at Texpo 1989, the then-CEO of VPL Jaron Lanier escorted his audience on a virtual promenade through a hospital's wards (Woods, 1989). The link between biomedicine and virtual reality came to be reinforced in the following years: after Lanier's eviction in 1993, Walter Greenleaf - the CEO of a company developing telemedicine applications - acquired the patents for the VPL systems (Hamilton, 1998). Many successful applications of virtual realities in the fields of medical imagery, biochemistry and rehabilitation have been documented in the early scientific symposia devoted to these topics, such as, for example, 'Medicine Meets Virtual Reality' or 'Virtual Reality and Persons with Disabilities'.

If, at the beginning of the 1990s, virtual reality (VR) technologies were welcomed as an alternative corporeal modality, they were also regarded as bearing the promise of a 'new world order of medicine' (Satava, 1994) in which information technologies would be more than simple tools for human creativity, and would return to being an institutional apparatus for public health and prophylaxis (Naj, 1993; Rosenberg, 1994).

Present-day ubiquitous and pervasive media, as well as the 1980s discourse of virulence and the virtual utopias of the 1990s, all actually express, albeit in 


\section{different forms, the same regime of anxieties and expectations about bodily regeneration by means of information and communication technologies.}

\section{Acknowledgements}

The author would like to thank Mr Olivier Boisseau from the website oldcomputers.com, who kindly provided bibliographical references for the images examined. Steven Corcoran (UNSW, Sydney), Paola Tubaro (University of Greenwich) and two anonymous referees have enriched the text with their commentaries.

\section{Notes}

1. The texts analysed stem from the archives of the online service LexisNexis Executive (last accessed through the servers of the Nottingham Trent University in May 2007). Research was conducted under the category 'major international publications' in English. Keywords: +hacker. +computer crime, +hacking.

2. The online archives of the hacker fanzine Datenschleuder available on the website ds.ccc.de, were last accessed through the servers of the École des Hautes Études en Sciences Sociales (France) in January 2007.

3. The images, located in a database accessible on the website www.oldcomputers.org, were consulted in May 2008 through the servers of the École des Hautes Études en Sciences Sociales (France).

4. In this article, I prefer the expression 'autonomous computing' over 'free computing' to describe the participatory and non-institutional usage of information and communication technologies. The notion is loosely inspired by that of 'autonomous technology' introduced by Dyer-Witheford (1994) and Di Corinto and Tozzi (2002). As such, it is closer to the political context of the early 1980 s and less prone to anachronism than the notions of 'free' or 'open' computing (Raymond, 1998).

5. Although their existence was attested in the 1970s, it was only in the following decade that electronic viruses started to be perceived as an actual danger by the software engineering community. The first scientific article analysing and defining them is Cohen (1984).

6. This assumption is developed in Kocher (1989).

7. In a memorable case dating back to August 1983, the radiotherapy department of New York's Sloan-Kettering Cancer Center was infiltrated by the members of the ' 414 gang', a hacker collective from Milwaukee. Probably performed by mistake and promptly interrupted, the access was depicted in sinister tones in media reports. In this case, the system administrators at the Sloan-Kettering Cancer Center solved the problem by simply sending the hackers a message asking them to stop their jokes which they did immediately. There was no damage to the system.

8. For a complete reconstruction see Mungo and Glough (1992).

9. No American addresses were targeted and the diskette's licence agreement formally banned distribution and use of the software in the US. See Anon. (Popp, Joseph L.?) (1989).

10. The domestication of computers, which some commentators date back to the mid 1990s (Cummings and Kraut, 2002; Frohlich and Kraut, 2003; Kraut et al., 2006), was actually a distinctive phenomenon of the previous decade.

11. One of the milestones in Apple's rise to commercial supremacy was a computer christened Lisa, named after Steve Job's daughter. In the 1980s, another big hitter was Commodore's Vic20, whose name, according to its creator, 'sounded like a truck driver' (Bagnall, 2003).

12. Among the best-known examples of computer names inspired by childhood are: the IBM PC jr, the Japanese Junior100 and the Danish RC Piccolo. Animal and fruit names were also commercially 
successful: for example, the Commodore's Pet was followed by BWV's Husky and by Applied Technologies' MicroBee; early European competitors of Apple included Acorn computers and Apricot PC.

13. After 1982, a number of short-lived home computers with pretentious names popped up: the Welsh Dragon Data, the English Atom, the Belgian Charlemagne 999, the French Orchidée as well as the American Vixen were all forced out of the market by 1984.

14. For a complete description see Linzmayer (1999) and Friedman (2005).

15. 'Rushing through the phone line like heroin through an addict's veins, an electronic pulse is sent out, a refuge from the day-to-day incompetencies is sought.... [...] We exist without skin color, without nationality, without religious bias ... and you call us criminals. [...] My crime is that of judging people by what they say and think, not what they look like’. (The Mentor, 1986).

16. Now established as a landmark publication in hacker history, Die Datenschleuder: Das wissenschaftliche Fachblatt für Datenreisende [The Data Catapult: A scientific journal for Infonauts] was initially published as a xeroxed newsletter by the Chaos Computer Club (CCC). This historical collective of anarchist and autonomen computer activists first made international news in 1984, when the German computer network Bildschirmtext was hacked. CCC members managed to withdraw a large sum of money from a Hamburg bank. Along with typical hacker bravado, the CCC founders displayed a certain 'gentlemen Marxist thieves' integrity: the money was soon returned and the act remained simply a bold commentary on the financial system's greed.

17. The phrase, created at the end of the 1980 s by the art collective Critical Art Ensemble as the title of a joint project with ACT UP, was later to be popularized in Critical Art Ensemble (1996).

18. The founder of Aids Treatment News, John James, was also the initiator of the seminal Bay Area 'virtual community' CommuniTree (Stone, 1991). The director of Critical Path, Kiyoshi Kuromiya, was a top name in the electronic activist milieu of Philadelphia.

\section{References}

Abrahams, P. (1988) 'Corporate Security: High-Tech Hits the Old Guard', Financial Times 22 November.

Ang, I. (1985) Watching Dallas: Soap Opera and the Melodramatic Imagination. London: Methuen.

Anon. (1982) 'Homo Communicans', picture in TeleSoft 1: 3.

Anon. (1983a) 'TI99/4A: L'Ordinateur Familial', picture in Tilt 3: 23.

Anon. (1983b) 'Donnez-lui votre rythme cardiaque et votre age, il vous donnera la forme', ad in Micro07 3: 6.

Anon. (1986a) 'Die Bratenschleuder: Gastrokybernetische Appetithappen', picture in Die Datenschleuder 17: 13.

Anon. (1986b) 'Viromat Plus', picture in Die Datenscbleuder 15: 17.

Anon. (1987) 'No Title', picture in Die Datenschleuder 19: 1.

Anon. (1988) 'No Title', picture in Die Datenschleuder 28-9: 2.

Anon. (Popp, J.L.?) (1989) 'Licence Agreement - AIDS Information Introductory Disk'. Brochure. Panama City: PC Cyborg Corp.

Associated Press (1988) ‘Computer Viruses are High-tech Counterparts of Biological Viruses', Neweswire 3 November.

Associated Press (1990a) 'Man Held on “AIDS” Disc Charge', Newswire 2 February.

Associated Press (1990b) 'Man Accused of Computer Extortion Says He Was Set Up', Newswire 4 February.

Babiole, C. (1992) Les Réalités virtuelles, documentary film. Paris: Canal.+

Baecque, A. de (1993) Le Corps de l'histoire: metaphores et politique, 1770-1800. Paris: CalmannLévy. 
Bagnall, B. (2003) 'Commodore - Vic20', Old Computers, URL (consulted September 2009): http:// www.old-computers.com/museum/computer.asp?c $=252 \& s t=1$

Barlow, J.P. (1990) 'Being in Nothingness: Virtual Reality and the Pioneers of Cyberspace', Mondo 2000 2: 34-43.

Bell, D.J. (2007) Cyberculture Theorists: Manuel Castells and Donna Haraway. London: Routledge. Bell, D.J., B. Loader, N. Pleace and D. Schuler (2004) Cyberculture: The Key Concepts. London: Routledge.

Berkeley, E.C. (1949) Giant Brains: Machines that Think. New York: John Wiley and Sons.

Berthelot, J.-M. (1992) 'Du corps comme opérateur discursif, ou les apories d'une sociologie du corps', Sociologie et sociétés 29(1): 11-18.

Bradley, B. (1988) “'Non-techies” Could Be Hurt by Virus', Christian Science Monitor 80(118): 22.

Brasier, M. (1990) 'No Bail in Virus Blackmail Case', The Guardian 3 February.

Burguière, A. (1999) 'L’Anthropologie historique et l'École des Annales', Les Cabiers du Centre de Recherches Historiques 22, URL (consulted September 2009): http://ccrh.revues.org/ index2362.html

Burke, P. (1986) 'Strengths and Weaknesses in the History of Mentalities', History of European Ideas 7(5): 439-51.

Casilli, A.A. (2009a) 'L'Adieu au corps n'a jamais eu lieu', Esprit 353: 151-3.

Casilli, A.A. (2009b) 'Le Stéthoscope et la souris: savoirs médicaux et imaginaires numériques du corps', Esprit 343: 175-88.

Chartier, R. (1998) Au bord de la falaise: l'bistoire entre certitudes et inquietude. Paris: Albin Michel.

Cohen, F.B. (1984) 'Computer Viruses: Theory and Experiments', pp. 240-63 in Proceedings of the 7th DoD/NBS Computer Security Conference. Gaithersburg, MD: National Bureau of Standards.

Connor, S. (1991) 'Doctor Popp and the Trojan Horse', The Independent 1 December.

Cooper, M. (2006) 'Pre-empting Emergence: The Biological Turn in the War on Terror', Theory, Culture E Society 23(4): 113-35.

Critical Art Ensemble (1996) Electronic Civil Disobedience and Other Unpopular Ideas. Brooklyn, NY: Autonomedia.

Cummings J.N. and R. Kraut (2002) 'Domesticating Computers and the Internet', The Information Society 18(3): 221-31.

De Certeau, M. (1975) L'Ecriture de l'bistoire. Paris: Gallimard.

Detrez, C. (2002) La Construction sociale du corps. Paris: Seuil.

Di Corinto, A. and T. Tozzi (2002) Hacktivism: la libertà nelle maglie della rete. Rome: Manifestolibri.

Dizzy (1989) 'Darf Zu Prüfzweckern von des Post Geöffnet Werden ...', picture in Die Datenschleuder 30: 1.

Dyer-Witheford, N. (1994) 'Autonomist Marxism and the Information Society', Capital E Class 52: 85-125.

Epstein, S. (1995) 'The Construction of Lay Expertise: AIDS Activism and the Forging of Credibility in the Reform of Clinical Trials', Science, Technology, E Human Values 20(4): 408-37.

Epstein, S. (1996) Impure Science: AIDS, Activism, and the Politics of Knowledge. Berkeley, CA: University of California Press.

Fairclough, N. (2003) Analysing Discourse: Textual Analysis for Social Research. London: Routledge.

Featherstone, M. (2007) 'Ubiquitous Media: Introduction', Theory, Culture E Society 24(7-8): 319-22.

Fraiberg, A. (1991) 'Of Aids, Cyborgs, and Other Indiscretions: Resurfacing the Body in the Postmodern', Postmodern Culture 1(3), URL (consulted September 2009): http://pmc.iath.virginia.edu/ text-only/issue.591/fraiberg.591 
Friedman, T. (2005) Electric Dreams: Computers in American Culture. New York: NYU Press.

Frohlich, D. and R. Kraut (2003) 'The Social Context of Home Computing', pp. 127-62 in R. Harper (ed.) Inside the Smart Home: Ideas, Possibilities and Methods. London: Springer.

Geary, J. (2002) The Body Electric: An Anatomy of the New Bionic Senses. London: Weidenfeld and Nicolson.

Gibson, W. (2007) Spook Country. New York: Putnam.

Gillett, J. (2003) 'Media Activism and Internet Use by People with HIV/AIDS', Sociology of Health E Illness 25(6): 608-24.

Grundner, T.W. and R.E. Garrett (1986) 'Interactive Medical Telecomputing: An Alternative Approach to Community Health Education', New England Journal of Medicine 314(15): 982-5.

Hamilton, J. (1998) 'Sun's Big Burst into Virtual Reality', Business Week Online 6 February, URL (consulted September 2009): http://www.businessweek. com/bwdaily/dnflash/feb1998/ nf80206g.htm

Hansen, M.B.N. (2006) Bodies in Code: Interfaces with New Media. New York: Routledge.

Haraway, D.J. (1985) 'A Cyborg Manifesto: Science, Technology, and Socialist-feminism in the Late Twentieth Century', Socialist Review 15(2): 424-57.

Haraway, D. (1989) 'The Biopolitics of Postmodern Bodies: Determinations of Self in Immune Systems Discourse', Differences: A Journal of Feminist Cultural Studies 1(1): 3-43.

Harrison, M. (1988) 'Security Gets Intensive Care: Medical Groups Step Up Protection', Financial Post 6 June.

Hayles, N.K. (2009) 'RFID: Human Agency and Meaning in Information-intensive Environments', Theory, Culture E Society 26(2-3): 47-72.

Ikegami, C. (1997) 'HIV Prevention and Community-based Organizations in Japan', Journal of Acquired Immune Deficiency Syndromes E Human Retrovirology 14(suppl. 2): 51-7.

James, J.S. (1988a) 'AIDS Computer Conference from Stockholm', Aids Treatment News 57(20 May). James, J.S. (1988b) 'Scientific Justification for Community-based Trials', Aids Treatment News 65(23 September).

Kalifa, D. (2008) 'What Is Now Cultural History About?', pp. 47-56 in R. Gildea and A. Simonin (eds) Writing Contemporary History. London: Hodder Education.

Kocher, B. (1989) 'A Hygiene Lesson', Communication of the ACM 32(1): 3-6.

Knorr Cetina, K. and A. Preda (2007) 'The Temporalization of Financial Markets: From Network to Flow', Theory, Culture E Society 24(7-8): 116-38.

Kraut, R., M. Brynin and S. Kiesler (eds) (2006) Computers, Phones, and the Internet: Domesticating Information Technology. New York: Oxford University Press.

Krishnamurthy, S. (2004) Contemporary Research in E-marketing. Hershey, PA: Idea Group Publishing.

Kroker, A. and M. Kroker(eds) (1987) Body Invaders: Panic Sex in America. New York: St Martin's Press.

Large, P. (1989) 'Virus Attack on City Computers Foiled', The Guardian 14 December.

Le Breton, D. (1999) L'Adien au corps. Paris: Métailié.

Lévy, P. (1994) L'intelligence collective: pour une antbropologie du cyberspace. Paris: La Découverte.

Linzmayer, O.W. (1999) Apple Confidential: The Real Story of Apple Computer Inc. San Francisco, CA: No Starch Press.

Lupton, D. (1994) Moral Threat and Dangerous Desires: AIDS in the News Media. London: Taylor and Francis.

McCloskey, D.N. (1988) 'Thick and Thin Methodologies in the History of Economic Thought', pp. 245-58 in N. de Marchi (ed.) The Popperian Legacy in Economics. Cambridge: Cambridge University Press.

The Mentor (pseud. L. Blankenship) (1986) 'Hacker Manifesto: The Conscience of a Hacker - January 8, 1986', Phrack 1(7), URL (consulted September 2009): www.phrack.org/issues.html?issue=7 
Moravec, H. (1988) Mind Children: The Future of Robot and Human Intelligence. Cambridge, MA: Harvard University Press.

Mungo, P. and B. Glough (1992) Approaching Zero: The Extraordinary Underworld of Hackers, Phreakers, Virus Writers, and Keyboard Criminals. New York: Random House.

Murche, J. (1989) 'Rogue Disks Hit Computers', The Advertiser 15 December.

Muri, A. (2003) 'Of $S * * *$ and the Soul: Tropes of Cybernetic Disembodiment in Contemporary Culture', Body E Society 9(3): 73-92.

Naj, A.K. (1993) 'Virtual Reality Isn't a Fantasy for Surgeons', Wall Street Journal 3 March.

Ory, P. (2004) L'Histoire culturelle. Paris: Presses Universitaires de France.

Painter, A. (2002) Viral Politics: The Power of E-campaigning. London: Politicos.

Pane, P.J. (1990) 'Man Arrested in AIDS Disk Blackmail Scheme', InfoWorld 12 February.

Peak, S. (1988) 'Hackers Could Identify IVF Dads', The Herald 23 June.

Poirrier, P. (ed.) (2008) L'Histoire culturelle: un tournant mondial dans l'bistoriographie? Dijon: Éditions Universitaires de Dijon.

Raymond, E.S. (1998) 'Homesteading the Noosphere', First Monday 3(10), URL (consulted September 2009): http://firstmonday.org/htbin/cgiwrap/bin/ojs/index.php/fm/article/view/621/542

Rheingold, H. (1993) The Virtual Community: Homesteading on the Electronic Frontier. New York: HarperCollins.

Richards, L. (1988) 'The Appearance of Youthful Subculture: A Theoretical Perspective on Deviance', Clothing and Textiles Research Journal 6(3): 56-64.

Richman, S. (1989) 'Common Sense Helps in Virus Battle', Washington Times 20 December.

Rodgers, S. (1985) 'Medical Files Easy Prey to Hackers', Courier-Mail 23 July.

Rosenberg, L.B. (1994) 'Medical Applications of Virtual Reality', Virtual Reality Systems 1(3): 48-50.

Rosenberg, R. (1988) 'Wired and Vulnerable', Boston Globe 6 December.

Ross, D.J. (1992) 'Persons, Programs and Uploading Consciousness', Extropy 9: 12-16.

Satava, R.M. (1994) 'Virtual Reality and the New World Order of Medicine', Virtual Reality Systems 1(3): 6.

Scott, R. (1984) '1984: Apple MacIntosh', TV commercial by CHIAT/DAY.

Singer, L. (1993) Erotic Welfare: Sexual Theory and Politics in the Age of Epidemic. London: Routledge.

Sterling, B. (1986) 'Introduction to Mirrorshades', pp. 1-13 in B. Sterling (ed.) Mirrorshades: The Cyberpunk Anthology. New York: Ace Books.

Sterne, J. (2006) 'The Historiography of Cyberculture', pp. 17-28 in D. Silver and A. Massanari (eds) Critical Cyberculture Studies. New York: NYU Press.

Stone, A.R. (1991) 'Will the Real Body Please Stand Up? Boundary Stories about Virtual Cultures', pp. 81-118 in M. Benedikt (ed.) Cyberspace: First Steps. Cambridge, MA: MIT Press.

Stone, A.R. (1996) The War of Desire and Technology at the Close of the Mechanical Age. Cambridge, MA: MIT Press.

Storey,J.(2006) Cultural Theory and Popular Culture: An Introduction. New York: Pearson Prentice Hall.

Tofts, D., A. Jonson and A. Cavallaro (eds) (2003) Prefiguring Cyberculture: An Intellectual History. Cambridge, MA: MIT Press.

Treichler, P.A. (1991) 'How to Have Theory in an Epidemic: The Evolution of AIDS Treatment Activism', pp. 57-106 in C. Penley and A. Ross (eds) Technoculture. Minneapolis, MN: University of Minnesota Press.

Turner, B.S. (1987) Medical Power and Social Knowledge. London: SAGE.

Van Loon, J. (2002) Risk and Technological Culture: Towards a Sociology of Virulence. New York: Routledge.

Venn, C., R. Boyne, J. Phillips and R. Bishop (2007) 'Technics, Media, Teleology: Interview with Bernard Stiegler', Theory, Culture \& Society 24(7-8): 334-41. 
Vigarello, G. (1988) Une Histoire culturelle du sport: techniques d'hier et d'aujourd'bui. Paris: Laffont. Waldby, C. (1996) AIDS and the Body Politic: Biomedicine and Sexual Difference. London: Routledge.

Wilder, C. (1988) 'Cashing in on Virus Anxieties', Computerworld 21 November.

Wodak, R. (2001) 'The Discourse-historical Approach', pp. 63-94 in R. Wodak and M. Meyer (eds) Methods of Critical Discourse Analysis. London: SAGE.

Wood, C. (1988) 'Crime in the Computer Age', Maclean's 25 January.

Woods, W. (1989) ‘Computer Guardian: The Sensation of a Shared Virtual Reality', The Guardian 13 July.

Antonio A. Casilli is a sociologist at the Edgar Morin Centre, EHESS (School for Advanced Studies in Social Sciences), Paris. His research interests include the social use of ICT, with a focus on health and computer-mediated communication. Among his publications are: Les Liaisons numériques (Seuil, 2010), Stop Mobbing (DeriveApprodi, 2001) and La fabbrica libertina (Manifesto Libri, 1997). He also authors the blog Bodyspacesociety.eu. [email: antonio.casilli@ehess.fr] 